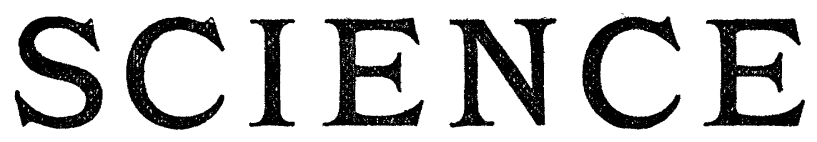

$\frac{\text { FrIDAY, NOVEMBER 12, 1909 }}{\text { The Teaching of English in a Scientific }}$

School: Professor A. T. Robinson ......

The Conditions affecting Chemistry in New York: Professor Morris LoEB .......... 664

Rare Birds in the New York Zoological Park: C. William Beebe ................ 668

International Conference on the Map of the World ............................

Mr. Kennedy's Bequests............... 669

Scientific Notes and News ............ 670

University and Educational News ........ 672

Discussion and Correspondence:Autonomy for the University: Dr. ALFRED G. MaYer. National Educational Responsibilities: Dr. Theo. B. CoMstock. International Language: Professor OtTo JesPERSON. Oxygen as well as Water proved to exist in the Atmosphere of Mars: DR.

Frank W. Very ................... 673

Quotations:-

The Harvard Medical School and Harvard

College ..............................

Scientific Books:-

Life and Letters of Peter and Susan Lesley: Professor J. J. Stevenson. The Cambridge Natural History: Professon THos.

H. Montgomery, JR. ..................

Scientific Journals and Articles:-

Internationale Revue der gesamten Hydrobiologie und Hydrographie: PROFESSOR

Chardes A. Kofoid ................ 684

The Treatment of Certain Tick-transmitted . Diseases: W. D. Hunter ............ 687

Special Articles:-

Demonstrations with the Musical Arc: W. B. HuFr. The "Rock Wall" of Rockwall, Texas: Sidney Paige. Apogamy in Enothera: Dr. R. R. GAtes. Membrane Formation and Pigment Migration in Sea Urchin E'ggs as bearing on the Problem of Artificial Parthenogenesis: E. Newton Harvey .... 688

Societies and Academies:-

The Philosophical Society of Washington: R. L. FARIS. The Chemical Society of Washington: J. A. LECLERC ............. 696

MSS. intended for publication and books, etc., intended for review should be sent to the Editor of SCIENCE, Garrison-onHudson, N. Y.

\section{THE TEACHING OF ENGLISH IN A SCIENTIFIC SCHOOL}

THE teacher of English in a scientific school faces in many ways a special problem. In a place where exact sciences are fundamental, he teaches an art which must often appeal to standards of taste. $\mathrm{He}$ finds always among his pupils a number who are at the start unsympathetic. Yet his subject is undoubtedly important. Aside from its practical value in training men in bearing and address, English composition may be made the basis of logical cultivation of the thinking powers, and the means of awakening in the mind the love of broader scholarship. On these accounts, if those interested in scientific education ask themselves how the time devoted to teaching English in scientific courses may best be employed, they are attacking a question by no means unimportant. In an attempt to throw some light on this question the present paper undertakes to deal with the broader aspects of the work in English composition as the writer has observed it during the last eight or nine years at the Massachusetts Institute of Technology.

Undergraduate instruction at the Institute of Technology is divided, as may be known, among thirteen prescribed courses of scientific and engineering studies, each of four years' duration. Without attempting to be precise, it may be stated roughly that the first two years are given up to studies which are regarded partly, or even mainly, as a means of general education. These subjects range from mechanical drawing, through elementary physics and chemistry, to history and economics. Some of them, like history, are purely eduea- 
tional; others, like drawing, have a distinct bearing on later professional work, but still are taught in the theoretical spirit, and with the purpose of developing power. To the latter class may be said to belong the subject of English composition. It is intended to furnish a tool for business and professional life; but at the same time it should serve to broaden the student's interests, to stimulate his power of observation, and to make him more alive to his inner mental process and better able to control it.

The time devoted to this subject is confined to two terms of fifteen weeks each during the first year of the four-year course. In the first term there are two class-room hours, and two hours of preparation each week. In the second term only half this time is allowed, and the division between class-room hours and preparation is left somewhat to the option of the instructor. When theme work is being assigned it is usual to consider two hours - the preparation period for the week-sufficient for the production of a theme of about three hundred words.

The work of instruction is carried on during the present year by a teaching force of eight persons. No detailed account of class-room methods is here intended, or would, indeed, be possible. The work has always been treated, by those responsible for its control, with a breadth and liberality which leave all possible scope for individual ingenuity in the teacher and for the adoption of new methods. To the writer, accustomed for some years to this large measure of freedom, it is inconceivable that work so dependent for its success on inspiration could be accomplished under any other system. At all events it is the happy privilege of those who teach English at the institute to regulate their own work, in all except its essential policy, and to adapt it, in so far as their various capacities allow, to their own powers and to the needs of the class. Under these conditions I must necessarily confine my account to a general view; and it is my purpose accordingly to discuss the underlying principles of this teaching, in so far as they seem likely to bear on the general problem of engineering education.

Students enter the institute on the basis of a high-school or college preparatory training. Therefore, as far as English is concerned, they come to us fresh from the study of the requirements adopted by the Commission of Colleges in New England. They have been reading selected works from the English classics, discussing their style and construction, writing appreciative essays about the characters which occur in them, or perhaps attempting "daily themes" on subjects of a supposedly more personal nature. In lieu of other models, however, we may fairly suppose that the style in this written work has been, consciously or unconsciously, molded after that of the classics studied. The works prescribed are, I believe admittedly, neither the most absorbing nor the most noble in the language. I doubt if they are such as the teacher himself would choose as the preferred companions of his idle moments; but rather they illustrate the general truth that we advise children and the young to undertake many tasks from which we ourselves should shrink. Of necessity, then, the college requirements in English are in many cases administered by the secondary school teacher as a medicine; and, in view of the pressure of preparatory work, in maximum doses. As a result of these conditions the engineering student enters the institute with strongly conceived notions about the study of English. He does not, as a rule, come of a "literary" family. Outside school requirements, his reading has been drawn chiefly from the Scientific American and perhaps the newspapers. In 
school he has read "literature." Literature, therefore, is, to his mind, like his school reading, either dry, silly or incomprehensible. By the same token English composition, the making of more literature, is an art in which he sees no practical value. For teachers, newspaper men and clergymen the thing may be well enough; but it requires a special gift of phrase-making which he feels rather glad to acknowledge that he lacks.

The teacher who successfully combats this prejudice has accomplished a delicate task in persuasion. He must work toward this end along three lines: he must give the incoherent and undeveloped mind respect for its own productions; he must remove, as far as may be, the embarrassment of his own too critical presence; and, finally, he must attempt to show, as no rules of English composition derived from the study of models of literature ever can show, a rational aim in writing and an easily attainable attitude of mind which will lead to success. This is essentially the problem of teaching English composition at the Institute of Technology.

In attempting to solve this problem it is essential, above all things and at the very start, to give the student respect for his new attitude as author and, at least in prospect, for his new product. With this aim in view the student is at the outset usually requested to select his own subjects for written work. His attention is called to the fact that success can come only with topics which he cares about and knows. At the beginning of the first term, and again later, as need arises, he hands in a short list of subjects on which he prefers to write. These are tested, in the first instance, only as to the degree of knowledge and personal interest behind them. In a large school like the institute, which draws its students from all parts of the world, and in some cases from men of business and professional experience, the subjects present considerable range and some novelty. There is first the immature school boy, graduated from a neighboring high school, who has seldom left his native town. He has his favorite sports to tell of, hunting and fishing trips, perhaps an occasional criticism of high-school methods or of institute life. Beside him is the student who has traveled or lived abroad, or in distant parts of the United States, and is full of information as to unfamiliar methods of life and work. Finally comes the young man of professional experience, who is ready and glad, if he can find an instructor or a fellow student well enough informed to follow him, to expound deep matters, like the theory of injectors, or fire-proof electric wiring. Common to all these writers, and more promising than other subjects, are those which relate to business methods or manufacturing processes engaged in or observed-"The Duties of a Stage Hand," "The Working of a Small Steamer," "Surveying with a Party in Pennsylvania." Of the students I have met in the last five years, only about two per cent. failed to respond to this method and declared themselves utterly devoid of ideas; the rest were rather easily supplied with congenial subjects, and started on work which from the beginning they could take seriously. It at once presented itself to the mind as worthy of respect, because entirely within the limits of their powers of expression, and likely to be valuable to the reader after it was done.

The subjects thus presented are, when possible, neostyle-copied and handed about the class. At all events it is essential that the students should have access to the list. This makes for the class work the hour of promise-nature putting forth her power "about the opening of the flower." The most possible should be made of it. It remains only to shield the actual product 
from too high a standard of criticism, and to provide each author, if possible, with sympathetic and intelligent readers. The class at large is no fitting audience. It demands, or seems to demand, too much, and frightens all but the more experienced or callous. Then again its mood is perhaps a little disingenuous. In attempting to hit its apparent taste one degenerates inevitably into smartness and after-dinner jesting. Individual critics chosen from among the students give better service. This plan may conveniently be followed if it is possible to neostyle-copy the lists of subjects. In that case each student explains briefly his proposed subjects, their general scope, method of treatment and point. Those who are interested in a particular subject signify their willingness to read the work, one of them is assigned as a critic, is later consulted by the author, and finally takes the instructor's place in giving a written criticism and correction of the finished theme.

This plan has some large theoretical advantages. It turns the youthful author over to critics of approximately his own age and experience. It relieves the teacher of some drudgery, and spares him the odium of fault-finding. Still, it should not be followed exclusively. One's fellow students are severe critics, but not usually sympathetic. Some will be misled by the titles, however fully explained, and find, perhaps, that they have more information than the author himself, or that they are not interested in the subject as he feels competent to treat it. Others will neglect to confer with the critics. This is perhaps the main danger. In the matter of instruction, both religious and secular, most of us think shame to adopt too serious an attitude, and even the boy who takes his studies most to heart will sometimes shrink from being known to do so. The whole question has been well handled by Mr. R.
G. Valentine, in a paper "On Criticism of Themes by Students," in the Technology Review, Vol. 4, p. 459. Mr. Valentine there discusses the advantages of the plan as adopted in his own institute classes at the time. Whatever drawbacks may accompany them, these advantages undoubtedly exist. A considerable portion of every student's work should unquestionably be read by his fellows, and, in classes sufficiently small for constant supervision, perhaps the whole. Such criticism, if taken seriously, soon removes the impression that the teacher's fault-finding is professional; and it takes composition into the field where it belongs-the field of practical dealing between man and man.

This relation between man and man, this sympathy on which all successful writing is based, must in the end, of course, depend upon the human quality of the teacher himself. He must learn, in a thousand ways, not to take up his position where he shuts out the light. The distance between an undergraduate and a man of over thirty, especially when the man is burdened with the moral awfulness of the teaching profession, is in itself considerable. With a little lack of sympathy, a little giving way to cheap sarcasm, the gap may become so wide as effectually to stop all communication. The student has at the start no notion that his teacher is human; and if in the end the teacher himself forgets that he is so, it will be well to dismiss the elass. The wise teacher, however, emphasizes points of contact, as he would in any other social relation. He resolves to be interested, instructed or amused. He looks upon the work handed him, not as an exercise which may contain interesting errors or violations of principles, but as an expression of character, however immature, and of attainments, however limited, such as he will not find precisely duplicated in any other person. He maintains 
a liberal and a cordial spirit in his criticisms. For the moment he sacrifices the ends of teaching for those of inspiration. If there be any virtue and if there be any praise, he looks on these things; and for his reward the reading of themes, which his friends all think must be deadly boredom, rises to the importance of an end in itself. It introduces him to a circle of congenial spirits, each furnishing for his entertainment the best that the mental stores can supply.

In the mass of material which the teacher reads-not of course without hours of discouragement-one element of interest is never lacking. He sees, at least, the working out of his own theories, and he watches a growth, however slow, implanted and tended by his own hand. For the rest, though his sympathy is sometimes an ideal state, much of what he reads would be interesting in any connection. In his classes he is constantly meeting men who, aside from spelling and the principles of composition, are better informed than he. These men he encourages to write of what they know. In the past five years I remember many pieces of work that could hardly have interested me more if they had been literary ventures of my own. One man, not so far removed from boyhood as to need a razor, wrote for me on the social life of boys, and it happened that his conclusions, largely illustrated from his own experience, were not unlike my own. I suppose I shall never read in print so frank and faithful an account of that period which usually goes unrecorded. I had a long paper on Colorado forest reserves and timber protection, from the son of a large timber owner. A boy who had been brought up abroad wrote a series of essays on German school life and customs. The thing which perhaps gave me most enjoyment in watching its growth was a fairly complete account of the Fore River works at Quincy, Mass. The author was engaged on this the better part of a term, partly in interviewing men and collecting material. I watched his work at every step. In the end he read large extracts to the class and showed the photographs which he had taken. In the public reading-and not till then-it dawned upon him that his style was rough, and, whereas at the opening of the term he had no notion of turning a sentence, he became in the end, without a hitch in the natural development of his mind, his own critic of style. These men were interesting and interested because met on their own ground. I might, if it had seemed expedient, have assigned them subjects in treating which they would have bored both themselves and me to extinction; but on the other hand I should dislike excessively to handle many subjects that they, if they had the upper hand, might assign to me.

It is not so hard, then, for the teacher to be sympathetic; but sympathetic he must be at any cost. To secure that end he must in most cases criticize orally, not in writing. The complete explanation in writing of even a minor fault will often require enough red ink to discourage the elect; and then, ten to one, the fault is no fault at all, but the result of some text-book principle, too narrowly applied. Oral criticism is more expressive, and at the same time more modest. It assumes that all is fundamentally right, ascertains the meaning by questions, conceals that usually large part of the difficulty which arises from the critic's own stupidity, and suggests a way out of the remaining trouble. All this is no chastisement, but a very human and urbane process; it is merely what occurs every day when two people talk on a congenial subject and try to arrive at an understanding.

In the substance of this eriticism as well there is a corresponding tempering of the 
wind. The criticism of details is for a time kept in the background. The instructor pretends to believe, what no one really believes in these days, that the secondary schools have found time to teach grammar, spelling and punctuation. Faults in these may be weeded out later, but for the present it is remarkably sound doctrine that to pull out the tares destroys the wheat. There is an old moral story of a merchant who, wishing to test the quality of two boys who had applied for work, gave each the half of a garret to be set in order. One, the hero of the tale, sorted all the rubbish with infinite pains, brads and tacks, crooked and straight. The other, with a fine impatience, swept things into heaps and threw them from the window. The second lost the place, but I confess he has my sympathy; he seems to me to have had a juster notion of relative values than the other. At all events his temper of mind is like that of the average student. No young man of promise will work conscientiously at correcting minor errors in work which is confessedly rubbish. He must seek first the task in which he can take a vital interest, and then all these things shall be added unto him.

Greater closeness of relation with the instructor, as well as the habit of writing for classmates, will both tend to bring out clearly the central problem of writingthe adaptation of work to a particular audience. Even when themes are written directly for the instructor, the attempt is usually made, by preliminary conferences with the student, to impress upon him that he is not writing for a general court of appeal, but for an individual mind, with definite prejudices, ascertainable limits of knowledge, and individuality of point of view. In teaching the writing of essays in literary criticism or of sonnets, the instructor may well set up to be the embodiment of the laws of taste and good use. If he is accused of urging as authoritative opinions which ought rather to be regarded as personal, he can hide behind a multitude of admitted classical instances where it is very hard indeed to find him. In attempting, on the other hand, to teach an engineering student straightforward English prose for business purposes, it is necessary to assume a somewhat simpler attitude. One says, not "This is bad," but "I dislike it"; not "Your expression lacks force," but "You have not brought your argument home to me, and thus you have failed; for your whole object was to produce an effect on my mind." The student who sees his work treated from this point of view begins to find the problem of writing simplified. Composition for him takes on the look of a practical art, for it is after all only one department of the great business for which he is being educated, the business of dealing with men. Before it had seemed a mystery, like the concoction of some foreign dish. A compound of so much force, so much unity, and the rest, would make a dainty to tickle the teacher's palate. One had first to get together the somewhat mysterious ingredients-by no means an easy task; and in the end one was left wondering whether the teacher had not acquired a perverted taste. Instead of these unnatural relations, the pupil who has been taught to write directly for some classmate or for his teacher finds himself in a simplified position where he knows definitely what is expected of him, can himself measure the degree of his success or failure, and may keep within a safe distance of the manner and the matter to which his daily life and his conversations with his fellows have accustomed him.

As the term progresses and men get the notion that their writing is to serve some useful end, all sorts of other plans may be tried. They may even be assigned subjects, of a reasonable sort. At some time during 
the term use is made of exercises bearing on the collection of facts and on observation, to the end that the student may in a degree learn how to observe, or at least to realize, why he has hitherto observed so little. To this end the class perhaps goes with the instructor to look at some relatively simple object, as the façade of a building. The natural sub-divisions are first discussed, and the order in which they may best be taken up; then the lines of observation essential to be followed in rendering each of these parts. After perhaps twenty minutes of this work, the men return with their notes to the class-room and write the report. Following this preliminary exercise under the eye of an instructor, more assignments are given out, of details of buildings, and features of natural or artificial interest about Boston, all being subjects on which the instructor has taken careful notes. The lesson of thorough and systematic observation thus begun is enforced by the assignment of subjects of a slightly different nature, from life, models or photographic enlargements. In all similar assignments for written work, the attempt is made to treat definite subjects, so that the results can be tested at any time, and criticized wholly, by an appeal to facts. Later in the year a more ambitious report is often attempted, involving not only natural but logical subdivisions, say on a neighborhood as a place of residence, or on a preparatory school. The subject is made general, but the student chooses that particular place or school with regard to which he has the most information. To help him in gaining what might be called self-consciousness, an articulate recognition of the ideas which are lying unrealized in his mind, he is given a list, as complete as it can be made, of the observations which would be pertinent, for instance the things necessary to be looked out for in selecting a place of residence.
It is usual in this work to leave the determination of the scope and mode of treatment to the student; and the result in most cases is a long, detailed, relatively mature, and often admirably arranged report, of from ten to fifteen pages of theme paper-the ordinary letter sheet.

These reports, thus constructed, are essentially like the engineering report of later years, and in this connection it is usual, when time permits, to study at least one engineering report, with an analysis of its headings, as showing the divisions of the subject, and the sort of observations which the engineer has thought it advisable to make under each head.

Thus there has been in the English instruction at the institute a conscious and, I believe, a conscientious effort to meet the conditions imposed by the needs of a technical school. The teaching differs fundamentally, both in spirit and in methods, from the instruction in English composition given in academic colleges. I myself was put through all the training offered in this line by one of the foremost eastern colleges; yet there were certain ideas which seem to me fundamental in the training. of engineers that, so far as I can remember, were never hinted to me. Part of the explanation for this is doubtless drawn from my undergraduate stupidity, but not all ; for I did absorb several strong impressions more or less opposed to these. It never occurred to me that fact is the background of all writing; or that a man has no business to write about matters of which he is ignorant; or that the substance is primary to the form; or that writing, like speech, is for the sole purpose of producing an effect upon some other mind and that all its laws must be derived from the consciousness of this fundamental principle.

The great present needs of such teaching 
of English composition as I have described are two. The first is closer contact with professional departments. Such contact has already been secured to some extent in the higher years, where professional reports are reviewed by members of the English department. This, however, is likely to resolve itself into a mere correction of faults in the technique of expression. What is needed rather is discussion and reports in which from the outset the teacher of engineering and the teacher of English shall cooperate; which shall be both conceived and carried out with the purpose not only of securing accuracy in details of fact, but also of studying the theories of thought and of expression which underlie such work. For instance, in connection with the reports spoken of above, it has for some time been a dream, unrealized as yet on account of tabular view adjustments and other practical difficulties, that first-year students might be taken in small sections, in the company of an instructor from an engineering department and another from the department of English, to study and report on some simple assignment along the lines of their chosen profession. The experiment, I believe, would be worth all the trouble of arrangement, and would do much in stimulating their powers of observation and in teaching them that the mastery of an English style is no ornamental acquisition, but the means of expressing yourself, your attainments and your facts, so as to become a moving force in the world.

The second need of this teaching is that of teachers. In other subjects, teachersthe good ones-are said to be born, not made. The ideal teacher of composition could hardly be born, for the limitations of human nature preclude him. To criticize all thought-the substance of it, from which alone the form depends-to sympathize with every point of view, to win the confidence of every type of mind-these tasks require some genuine magnanimity of soul. No man can fully meet so large a requirement, yet here and there are found persons not ill adapted on one side or another for the task. Nothing can come amiss-scraps of general information, breadth of interest, the power of drawing out other people's ideas, above all warmth of heart. Meanwhile with whatever equipment, lucky if with a trace of some necessary quality, one does one's best. It is at least something to have conceived the sort of man one ought to be.

$$
\begin{aligned}
& \text { A. T. Robinson } \\
& \text { Massachusetts Institute of Techology }
\end{aligned}
$$

\section{THE CONDITIONS AFFECTING CHEMISTRY IN NEW YORK ${ }^{1}$}

IN assuming the chair, I am confident that the coming year will be one of great progress in our section's history, not through any merit of its officers, but through the ever-increasing spirit of cooperation among the members, and the rapid strides which research and industry are making in this country. You will hear reports, this evening, of two important general meetings that interested our membership, that of our own society at Detroit and that of the International Congress of Applied Chemistry at London. In both, members of this section bore a worthy share, and it is a gratifying tribute to American progress in science and industry, that the International Congress chose America for its next meeting-place. It is not only the foreigner who lands at Ellis Island that deems America synonymous with New York, and the members of this section must be prepared to do their full duty, during the next three years, in order that our foreign brethren may carry back

\footnotetext{
${ }^{1}$ Address of the chairman of the New York Section of the American Chemical Society, delivered October 8, 1909.
} 